\title{
CrimRxiv
}

\section{Modernizing Crime Statistics: Report 2: New Systems for Measuring Crime}

National Research Council

Published on: Apr 23, 2018

DOI: $10.21428 / c b 6 a b 371.10964 d 0 e$

License: Creative Commons Attribution 4.0 International License (CC-BY 4.0). 
